\title{
Sulphomucins favour adhesion of Helicobacter pylori to metaplastic gastric mucosa
}

\author{
Juan C Bravo, Pelayo Correa
}

\begin{abstract}
Aims-To assess the influence of sulphomucin secretion on Helicobacter pylori colonisation and adhesion to metaplastic gastric cells.

Methods-Gastric biopsies from 230 $H$ pylori positive patients with intestinal metaplasia were analysed. Sulphated mucins and $H$ pylori were visualised using a new technique combining high iron diamine-alcian blue mucin stains with the Steiner silver stain for the bacteria.

Results-Sulphomucin secretion anywhere in the mucosa and a histological diagnosis of dysplasia increase the risk of $H$ pylori adhesion to metaplastic cells (odds ratios 19.9 and 4.3, respectively). However, only $9.4 \%$ of cases showing sulphomucin secretion and $10.8 \%$ of cases with dysplasia had evidence of adhesion of $H$ pylori bacteria to metaplastic cells. Conclusions-The findings suggest that $H$ pylori may play a role in the advanced stages of carcinogenesis. It will be of interest to investigate if the relative small proportion of type III metaplasias that actually progress to carcinoma show persistence of $\boldsymbol{H}$ pylori.
\end{abstract}

(F Clin Pathol 1999;52:137-140)

Keywords: gastric intestinal metaplasia; sulphomucins; Helicobacter pylori; carcinogenesis

Department of

Pathology, Louisiana

State University

Medical Center and

Stanley S Scott Cancer

Center, Department of

Pathology, 1901

Perdido Street, New

Orleans, Louisiana,

USA

J C Bravo

P Correa

Correspondence to:

Dr Correa

email: correa@1sumc.edu

Accepted for publication 19 October 1998
There is a general agreement that Helicobacter pylori increases gastric cancer risk $^{1-3}$ and that intestinal metaplasia of the gastric mucosa is a precursor of cancer. ${ }^{4}$ It is therefore somewhat paradoxical that colonisation by $H$ pylori takes place where normal gastric surface epithelial ("foveolar") cells are present, but not where they are replaced by metaplastic cells with intestinal phenotype. ${ }^{56}$ An exception to this rule has recently been reported by Genta $e t a l,{ }^{7}$ who documented adherence of $\mathrm{H}$ pylori to metaplastic cells with the "incomplete" phenotype, also known as "type III" or "colonic." The latter type of metaplasia is associated with

Table 1 Numbers of cases with histological diagnosis based on haematoxylin and eosin staining according to the presence of sulphomucins in columnar and goblet cells

\begin{tabular}{lllll}
\hline & \multicolumn{2}{l}{ Sulphomucins } & \\
\cline { 2 - 4 } Histological diagnosis & $G-C-$ & $G+C-$ & $G+C+$ & \multirow{2}{*}{ Total } \\
\hline Complete intestinal metaplasia & $92(86.0)$ & $15(14.0)$ & $0(0)$ & 107 \\
Incomplete intestinal metaplasia & $0(0)$ & $10(25.0)$ & $30(75.0)$ & 40 \\
Dysplasia & $0(0)$ & $24(28.9)$ & $59(71.1)$ & 83 \\
Total & $92(40.0)$ & $49(21.3)$ & $89(38.7)$ & 230 \\
\hline
\end{tabular}

Percentages in parentheses.

C, columnar cell; $\mathrm{G}$, goblet cell.

Overall $\mathrm{p}$ value $=0.0001, \chi^{2}$ test.

secretion of sulphomucins. ${ }^{8}$ We examined the spacial relation between $H$ pylori, metaplastic cells, and presence of sulphomucin secretion in biopsies from 230 patients from Nariño, Colombia.

\section{Methods}

Patients belong to a cohort with gastric cancer precursor lesions from the region of Nariño, Colombia, previously documented to have very high gastric cancer risk. ${ }^{9-11}$ The study was approved by the Louisiana State University institutional review board. Four biopsies were evaluated for each patient: two from the antrum (lesser and greater curvatures), one from the incisura angularis, and one from the corpus (mid-portion of anterior wall). Subjects were selected because of a previous diagnosis of intestinal metaplasia with or without dysplasia, documented with haematoxylin-eosin, PASalcian blue, and high iron diamine-alcian blue stains. ${ }^{12}{ }^{13}$ All patients had $H$ pylori infection confirmed by the Steiner modification of the Warthin-Starry silver stain. ${ }^{14}$ Visual analogue scales $^{15}$ were used to evaluate the density of $H$ pylori colonisation. Published models were compared with the cases under study, which were graded as normal, mild, moderate, and marked. The Genta stain ${ }^{16}$ was performed to detect $H$ pylori adherence to metaplastic cells expressing acid mucins. We developed a new technique using the high iron diamine-alcian blue method followed by the Steiner modification of the Warthin-Starry stain; this allows simultaneous visualisation of sulphated mucins, and $H$ pylori and was used when adherence to acid mucin was previously detected with the Genta stain (see appendix). On haematoxylin-eosin stains the metaplasia was classified as "complete" type (type I or small intestinal) when in addition to the goblet cells, absorptive enterocytes with well developed brush border constituted the only intestinal phenotype observed. If irregular multivacuolated cells without brush border characterised portions of the metaplastic mucosa, such areas were classified as "incomplete" type (type III or colonic). Such islands of incomplete metaplasia were in most cases also accompanied by topographically independent foci of complete metaplasia. The presence of sulphomucins was evaluated independently in goblet cells and columnar cells. In all cases where sulphomucins were present in columnar cells they were also present in goblet cells. Therefore two positive patterns were recorded: goblet cells positive only (G+C-) or both goblet and columnar cells positive $(\mathrm{G}+\mathrm{C}+)$. 
Table 2 Number of cases with adhesion of $H$ pylori bacteria to metaplastic cells according to the presence of sulphomucins

\begin{tabular}{lllll}
\hline \multirow{2}{*}{ H pylori adherent to IM } & \multicolumn{2}{l}{ Sulphomucins } & \\
\cline { 2 - 4 } & $G-C-$ & $G+C-$ & $G+C+$ & Total \\
\hline Negative & $92(42.4)$ & $47(21.7)$ & $78(35.9)$ & $217(100)$ \\
Positive & $0(0)$ & $2(15.4)$ & $11(84.6)$ & $13(100)$ \\
Total & $92(40.0)$ & $49(21.3)$ & $89(38.7)$ & $230(100)$ \\
\hline
\end{tabular}

Percentages in parentheses.

C, columnar cell; G, goblet cell; IM, intestinal metaplasia.

Overall $\mathrm{p}$ value $=0.001, \chi^{2}$ test

STATISTICS

Statistical analysis was performed using the $\chi^{2}$ method to compare frequencies. The MantelHaenzel test was used to analyse the relation between $H$ pylori adherence and sulphomucins after adjusting for the gastric intestinal metaplasia extension and bacteria density. The interaction analysis was performed using logistic regression. A probability $(\mathrm{p})$ value $<0.05$ was considered statistically significant.

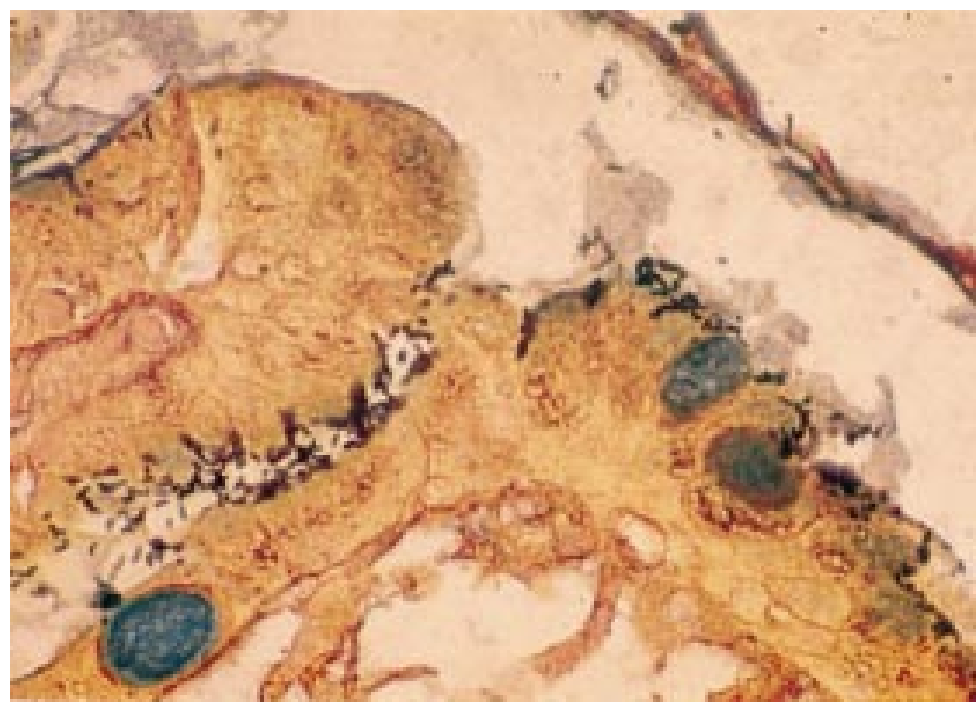

Figure 1 Photomicrograph of gastric biopsy showing colonies of H pylori on the gastric mucosa (long arrow) and as clusters adhering to sulphomucin secreting goblet cells (shor arrows). (Modified high iron diamine-alcian blue-Steiner stains; magnification $\times 82$.)

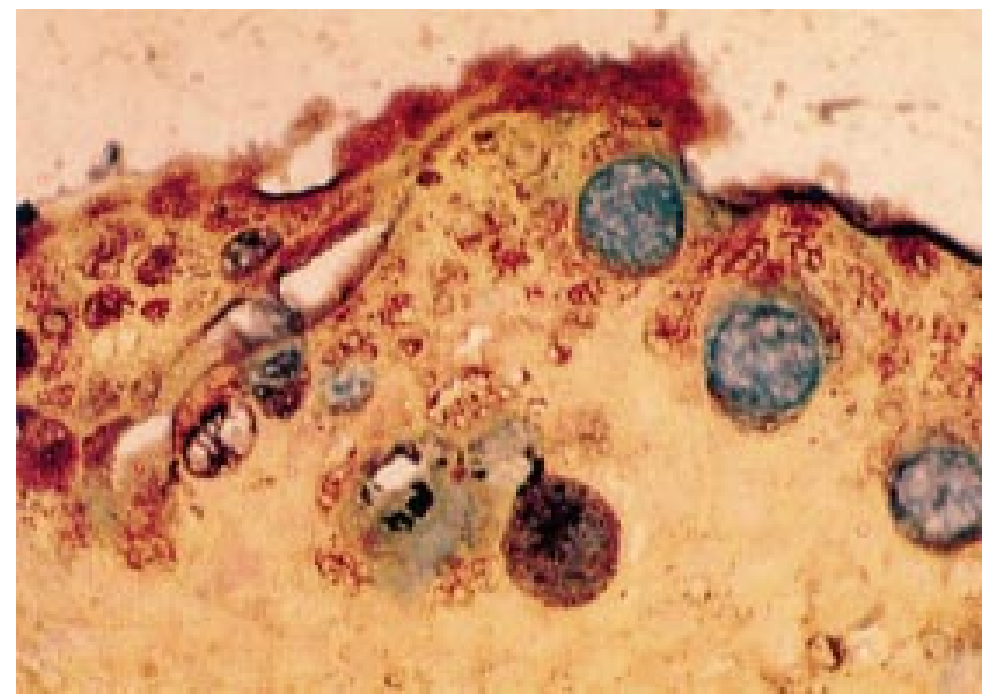

Figure 2 Photomicrograph of gastric biopsy showing adhesion of clusters of H pylori to the goblet cells expressing sulphomucins (Modified high iron diamine-alcian blue-Steiner stains; magnification $\times 82$.)

\section{Results}

For descriptive purposes, the relation between the presence of $H$ pylori in gastric tissue and sulphomucin distributions was studied in those biopsies with a histological diagnosis of gastric intestinal metaplasia.

Based on the analysis of all biopsies for 230 patients, table 1 shows the association between the type of metaplasia, as evaluated in haematoxylin-eosin stains, and the presence of sulphomucins in columnar and goblet cells. All cases of dysplasia had adjacent areas of incomplete intestinal metaplasia as well as sulphomucins. Fourteen per cent of cases with exclusively complete intestinal phenotype had some sulphomucins in goblet but not in columnar cells.

Table 2 shows a positive association between adhesion of $H$ pylori bacteria to metaplastic cells and the secretion of sulphomucins. Even though the specific site of sulphomucin secretion may not coincide exactly with the site of $H$ pylori presence, all specimens showing $H$ pylori adherence to metaplastic cells had sulphomucins somewhere in the section (figs 1 and 2). The odds ratio for bacterial adhesions given the presence of sulphomucins anywhere in the specimen was $19.9(p=0.002)$, indicating that sulphomucin secreting metaplasias are more likely to allow bacterial adhesions to metaplastic cells than those secreting only sialic mucins. If only columnar cells secreting sulphomucins are counted, the odds ratio was 9.8 $(\mathrm{p}=0.0001)$. In no case were bacterial adhesions to mucin goblets visualised in the absence of sulphomucin secretion somewhere in the specimen. Despite the strong association of sulphomucin secretion with bacterial adhesions, the effect was observed in only $9.4 \%$ of the patients (13/138).

Table 3 shows the association between bacterial adhesion and histological diagnosis based on haematoxylin-eosin stains. The odds ratio of bacterial adhesion, given the presence of incomplete intestinal metaplasia phenotype, was $26.3(p=0.001)$. A histological diagnosis of dysplasia increased the risk of bacterial adhesion by a factor of $4.3(p=0.010)$. All cases of dysplasia with bacterial adhesion were mild. Tables 2 and 3 reflect the close correlation between the histological classification of metaplasia by haematoxylin-eosin and by mucin histochemistry stains.

Table 4 shows a positive association between bacterial adhesion to metaplastic cells, the density of bacterial colonisation in the nonmetaplastic mucosa, and the extension of the gastric intestinal metaplasia. The phenomenon of $H$ pylori adherence and sulphomucins was correlated with extensive intestinal metaplasia $(p=0.032)$ and a severe degree of bacterial colonisation $(p=0.007)$. Even though $5.6 \%$ of the biopsies had $H$ pylori adherence to metaplastic cells, abundant colonisation by itself does not explain the adherence. A multivariate model (logistic regression) showed that, even after adjusting for the density of $H$ pylori, adherence was significantly more common in patients with extensive intestinal metaplasia. 
Table 3 Numbers of cases with bacterial adhesion according to histological diagnosis based on haematoxylin-eosin staining

\begin{tabular}{lllll}
\hline \multirow{2}{*}{ H pylori adherent to IM } & \multicolumn{2}{l}{ Histological diagnosis } & \\
\cline { 2 - 4 } & CIM & IIM & Dysplasia & Total \\
\hline Negative & $107(49.3)$ & $36(16.6)$ & $74(34.1)$ & $217(100)$ \\
Positive & $0(0)$ & $4(30.8)$ & $9(69.2)$ & $13(100)$ \\
Total & $107(46.5)$ & $40(17.4)$ & $83(36.1)$ & $230(100)$ \\
\hline
\end{tabular}

Percentages in parentheses.

CIM, complete intestinal metaplasia; IIM, incomplete intestinal metaplasia; IM, intestinal metaplasia.

Overall $\mathrm{p}$ value $=0.002$ by $\chi^{2}$ test

Table 4 Extension of gastric intestinal metaplasia and density of $H$ pylori colonisation according to H pylori adherent status

\begin{tabular}{llll}
\hline & \multicolumn{2}{l}{ H pylori adherent to IM } & \\
\cline { 2 - 3 } & Negative & Positive & Total \\
\hline $\begin{array}{l}\text { H pylori density } \\
\text { Scarce } \\
\begin{array}{c}\text { Abundant } \\
\text { IM extension }\end{array}\end{array}$ & $144(98)$ & $3(2)$ & $147(100)$ \\
$<60 \%$ & $73(88)$ & $10(12)$ & $83(100)$ \\
$\geqslant 60 \%$ & $115(99.1)$ & $1(0.9)$ & $116(100)$ \\
\hline
\end{tabular}

Percentages in parentheses.

IM, intestinal metaplasia.

Overall $\mathrm{p}$ value $=0.002$ by $\chi^{2}$ test.

\section{Discussion}

The reason for the preferential colonisation of $H$ pylori in gastric epithelial foveolar cells but not in metaplastic cells is unknown. Since the former secrete neutral mucins and the latter secrete acid mucins, it appears reasonable to suggest that mucin secretions determine colonisation in the gastric microenvironment. Neutral mucins may be a necessary nutrient, or acid mucins may be toxic for the bacteria. Our findings that bacterial colonisation occurred in metaplastic cells only if sulphomucins were secreted may indicate that some acid mucins are not toxic - that is, those containing sulphur atoms may allow bacterial growth in their immediate vicinity. By inference, it could be proposed that sulphomucins may provide some nutrient for helicobacter bacteria.

$H$ pylori has been classified as a human carcinogen. ${ }^{2}$ The mechanism of cancer induction and the stage at which it takes place are unknown. Since $H$ pylori induces inflammation decades before an eventual neoplastic outcome, it would be logical to assume that the effect takes place early in the process of carcinogenesis. However, it has been suggested that oxygen radicals produced during the inflammatory process may induce DNA damage and eventually cause neoplastic transformation. ${ }^{17}$ Such radicals are present as long as there is inflammation and may therefore damage DNA at all stages of the carcinogenic process. That $H$ pylori may play a role in advanced stages of the carcinogenic process has been suggested recently by Uemura et al in a non-randomised clinical trial. ${ }^{18}$ Their preliminary study reports that successful treatment of $H$ pylori infection reduces the risk of metachronous cancer after endoscopic resection of gastric carcinoma limited to the mucosa. Although their report needs replication, it provides an interesting suggestion for further research.
If $H$ pylori plays a role in the late stages of gastric carcinogenesis, the presence in sulphomucins secreting metaplastic cells may be involved mechanistically. H pylori has been shown to be capable of catalysing nitrosation reactions $^{19}$ and participating in $\mathrm{N}$-acetyltransferase activities. ${ }^{20}$ It is therefore possible that the presence of the bacteria in the vicinity of dysplastic cells contributes to the progression of the precancerous process. As mentioned above, oxygen radicals induced by bacteria may produce DNA damage. If the target is a dysplasic cell, further mutations may result in invasive neoplastic clones.

Our findings confirm those of Genta et al and Steadman et al. ${ }^{21}$ Further elucidation of these observations may help understand the microenvironmental requirements of $H$ pylori colonisation in the human gastric mucosa as well as the mechanism by which $H$ pylori infection increases the risk of gastric cancer.

This study was supported by grant PO1-CA-28842 of the National Cancer Institute, NIH, USPHS.

\section{Appendix}

Staining procedure for high iron diamine-alcian blue-Steiner method

1 Preclean glass slides and glassware using the following steps:

$10 \%$ nitric acid, $1 \mathrm{~h}$ Running tap water, $15 \mathrm{~min}$ Deionised water, 4 times Dry up at $60^{\circ} \mathrm{C}$ or at room temperature

2 Cut $5 \mu \mathrm{m}$ tissue sections. Heat fix them to the glass slides for $1 \mathrm{~h}$ or overnight at $60^{\circ} \mathrm{C}$

3 Deparaffinise and hydrate to distilled water: Three changes of xylene, 5 min each

Two changes of absolute ethanol and two changes of $95 \%$ ethanol, 3 min each

Wash thoroughly in running tap water for at least 2 min

4 Stain for 18 to $24 \mathrm{~h}$ in freshly prepared high iron diamine solution; keep in the dark at room temperature

5 Rinse "in and out" with distilled water

6 Alcian blue solution, $30 \mathrm{~min}$ (filter before use)

7 Rinse "in and out" with distilled water

8 Rinse with deionised water, 4 times

9 Microwave in $1 \%$ uranyl nitrate (100\% power), $2 \mathrm{~min}$

10 Let stand at room temperature, $5 \mathrm{~min}$

11 Rinse with deionised water, 4 times

12 Microwave in $1 \%$ silver nitrate ( $100 \%$ power), $2 \mathrm{~min}$

13 Let stand at room temperature, $10 \mathrm{~min}$

14 Rinse with deionised water, 4 times

15 Five dips in $95 \%$ ethyl alcohol and five dips in absolute alcohol

$162.5 \%$ gum mastic, $5 \mathrm{~min}$

17 Air dry the sections, $1 \mathrm{~min}$

18 Microwave the reducing solution (100\% power), 1.5 $\min$

19 Add the $0.04 \%$ silver nitrate and immerse the slides

20 Let stand at room temperature, $2 \mathrm{~min}$

21 Microwave the reducing solution ( $30 \%$ power), $2 \mathrm{~min}$

22 Let stand at room temperature, $3 \mathrm{~min}$

23 Take out the positive control, rinse it in deionised water five dips and in 95\% alcohol five dips. Check under the microscope, it should show black spirochetes in a light yellow background; if is not good return it to the stain container and microwave (30\% power) 2 min plus $2 \mathrm{~min}$ at room temperature and check it again.

24 Rinse with deionised water to stop reduction, 4 times

25 Dehydrate through graded alcohols and clear in xylene

26 Mount with synthetic resin. 
Results

Most sulphomucins stain dark brown to black, sialomucins stain blue. Helicobacter pylori stains black. Background yellow.

1 Correa P. Helicobacter pylori and gastric carcinogenesis. $\mathrm{Am}$ f Surg Pathol 1995;19(suppl 1):S37-43.

2 International Agency for Research on Cancer. Infections with schistosomes, liver flukes and Helicobacter pylori. Evaluation of carcinogenic risks to humans. Lyon: IARC, 1994.

3 Correa P. Helicobacter pylori and gastric cancer: State of the Art. Cancer Epidemiol Biomarkers Prev 1996;5:477-81.

4 Correa P. A human model of gastric carcinogenesis. Cancer Res 1988;48:3554-60.

5 Craanen ME, Blok P, Dekker W, et al. Subtypes of intestina metaplasia and Helicobacter pylori. Gut 1992;33:597-600.

6 Testoni P, Colombo E, Scelsi R, et al. Tissue staining for Helicobacter pylori in intestinal metaplasia: correlation with its extension and histochemical subtypes. Ital $f$ With its extension and hist

7 Genta RM, Gurer IE, Graham DY, et al. Adherence of Helicobacter pylori to areas of incomplete intestinal metaplasia in the gastric mucosa. Gastroenterology 1996;111: plasia in

8 Jass JR, Filipe MI. Sulphomucins and precancerous lesions of the human stomach. Histopathology 1980;4:271-9.

9 Correa P, Haenszel W, Cuello C, et al. The gastric precancerous process in a high risk population: crosssectional studies. Cancer Res 1990;50:4731-6.

10 Correa P, Haenszel W, Cuello C, et al. Gastric precancerous process in a high risk population: cohort follow-up. Cancer Res 1990;50:4737-40

11 Correa P, Cuello C, Duque E, et al. Gastric cancer in Colombia. III. Natural history of precursor lesions. $\mathcal{F}$ Nat Cancer Inst 1976;57:1027-35.
12 Luna LG. PAS-Alcian blue method for mucosubstances, $\mathrm{pH}$ 2.5. In: Luna LG, ed. Manual of histologic staining methods of the Armed Forces Institute of Pathology, 3rd ed. New York: McGraw Hill, 1968:168-9.

13 Spicer SS. Diamine methods for differentiating mucosubstances histochemically. F Histochem Cytochem 1965;13: 211-34.

14 Garvey W, Fathi A, Bigelow F. Modified Steiner for the demonstration of spirochetes. $\mathcal{F}$ Histotechnol 1985;8:15-17.

15 Dixon MF, Genta RM, Yardley JH, et al. Classification and grading of gastritis. The updated Sydney System. International Workshop on the Histopathology of Gastritis, Houston 1994. Am f Surg Pathol 1996;20:1161-81.

16 Genta RM, Robason GO, Graham DY. Simultaneous visualization of Helicobacter pylori and gastric morphology: a new stain. Hum Pathol 1994;25:221-6.

17 Mannick EE, Bravo LE, Zarama G, et al. Inducible nitric oxide synthase, nitrotyrosine, and apoptosis in Helicobacter pylori gastritis: effect of antibiotics and antioxidants. Cancer Res 1996;56:3238-43.

18 Uemura $\mathrm{N}$, Mukai $\mathrm{T}$, Okamoto $\mathrm{S}$, et al. Effect of Helicobacter pylori eradication on subsequent development of cancer after endoscopic resection of early gastric cancer. Cancer Epidemiol Biomarkers Prev 1997;6:639-42.

19 Ziebarth D, Spiegelhalder B, Bartsch H. N-nitrosation of medicinal drugs catalysed by bacteria from human saliva and gastro-intestinal tract, including Helicobacter pylori. Carcinogenesis 1997; 18:383-9.

20 Chung JG, Wang $\mathrm{HH}$, Tsou MF, et al. Evidence for arylamine $\mathrm{N}$-acetyltransferase activity in the bacterium Helicobacter pylori. Toxicology 1997;91:63-71.

21 Steadman C, Teage C, Kerlin P, et al. Campylobacter pylori in gastric antral intestinal metaplasia [letter]. Gastroenterology 1988;95:258-60. 